\title{
Exoticism of Barongan Kusumojoyo Demak Regency: The Art of East Coast of Central Java
}

\author{
R S Sundari ${ }^{1}$, T R Rohidi' ${ }^{2}$ S A Sayuti ${ }^{3}$, and Hartono ${ }^{4}$ \\ ${ }^{1}$ Universitas PGRI Semarang, Semarang, Indonesia \\ ${ }^{2,4}$ Universitas Negeri Semarang, Semarang, Indonesia \\ ${ }^{3}$ Universitas Negeri Yogyakarta, Yogyakarta, Indonesia \\ E-Mail: ririssetyo@upgris.ac.id
}

\begin{abstract}
Javanese people has variety arts as part of culture, the one is Barongan. Barongan was born and lived side by side with the lives of the people who owned it. Barongan Kusumojoyo Arts of Demak Regency is one of the Barongan arts found on the east coast of Central Java. Barongan Kusumojoyo art is still maintained its existence until now. The purpose of this study is to examine the form of Barongan Kusumojoyo in Demak Regency. This research is a qualitative research that uses observation, interview, and document study techniques in data collection. The data validity techniques used is the extension of observation, triangulation, and peer examination. The data analysis technique is done by doing data reduction, data presentation, and drawing conclusions. The results showed that the performance process of Barongan Kusumojoyo in Demak Regency consisted of 5 (five) sections, namely (1) jathilan, (2) barongan, (3) songs, (4) jokes, and (5) attractions. The supporting elements of the Brongan Kusumojoyo show in Demak Regency are: (1) dancers, (2) music players, (3) comedians, (4) attractions handler, (5) singers, (6) properties, (7) offerings.
\end{abstract}

Keywords: Barongan; Culture; Performance Art; East Cost Of Central Java.

\section{INTRODUCTION}

Javanese society is a society that has a variety of traditional arts. The art is the result of the creativity of the community as a supporter of its culture and is a characteristic of its people. Javanese people are people who use Javanese as their mother tongue, which is native to central and eastern Java. So in this case the Javanese people are not residents of Java, but the people who live within the circle of Javanese culture. Geographically, the circumference of Javanese culture is in the area of Central Java and East Java, while West Java is the circumference of Sundanese culture. There are so many traditional art that traditional arts live and develop in the 
lives of Javanese people as the supported community. The supported community, in addition, believes that this traditional art is not only acted as an entertainment, but also a facilitator for their hopes and prays [1]. Traditional arts are used to express the beauty of the human soul, and In traditional artwork implicit message of the society of knowledge, ideas, beliefs and values norms [2].

Barongan is one of the arts in the eastern coastal region of Central Java. Barongan Arts still lives and develops along with the lives of its people. At first, Barong was a form of ritual dance related to Totemism's belief, the belief in a four-legged animal that has the power to protect. [3]. Barongan art lives and develops in the lives of the people who own it. Barongan exists and is performed in various events held by the community such as circumcision, village cleaning ceremonies, ruwatan, weddings, or for big day celebrations. Barongan art in addition to functioning as entertainment, also has other functions, namely as a means of ritual. Barongan art is used as a medium to convey gratitude and respect to the creator of the universe. This study examines the forms of Barongan Kusumojoyo Regency's art performances as one of the traditional arts of the east coast of north Central Java.

Art is one form of culture that is characteristic of a society, and is also one of the basic human needs. According to Rohidi [4] ways of satisfying aesthetic needs are determined culturally (such as other aspects of culture), as well as integrated with other aspects of that culture. The process of satisfying aesthetic needs takes place and is governed by a set of values and principles that apply in society, and therefore tend to be realized and passed on to the next generation. Art is born together with human existence, and lives and develops together with human life. Tolstoi in Iswantara [5] says that art is an expression of the feelings of artists conveyed to others so that they can feel what they feel. Art becomes a medium for expressing what is in the human mind. Art is also a medium for communicating what has become an idea to be accepted by others. One branch of art that exists is performance art.

Performance art refers to a work of art created by an artist, as a form of expression of his thinking and ideas [6]. Barongan Arts is a structured system that has supporting elements of the performance. The elements of the performance work together and are useful for the continuity of a show. To assess the structure of the performance of Barongan Kusumojoyo in Demak Regency, functional structural theory by Talcot Parson was used. In this regards Parsons [7] states: art as social structure has the parts or elements of the system cannot be separated to stand alone, but rather an integrated system. Each part has a function on another part or also on the integrity of the system. The functions of each part are: interdependence between these parts is a function of mutual interdependence itself, and the parts support each other, support each other between the parts that form to maintain the overall integrity or system.

\section{METHOD}

This research is a qualitative research. In accordance with Creswell's statement [2] which states that qualitative research is interpretative research, this research interprets what is happening in the field, in this case Barongan Kusumojoyo, Demak Regency. The relationship between researchers and the object under study in this study is very important, considering that in qualitative research, researchers are the main key to interpreting data in the field. This study uses qualitative because it examines the art of Barongan Kusumojoyo in Demak Regency, related to the form of the performance. 


\subsection{Research Objectives}

The target in this study was Barongan Kusumojoyo art in Demak Regency. Barongan Kusumojoyo Arts of Demak Regency is one of the arts groups that displays barongan-shaped performing arts. This research will examine the form of barongan art performances as a show.

\subsection{Data Data Collection Technique}

\subsubsection{Observation}

One technique used for data collection in this study is observation. Observation was carried out by observing the process of art performing of Barongan Kusumojoyo in Demak Regency. Observation was also carried out by observing the process of preparing the performances performed by members of the arts group.

\subsubsection{Interview}

The next technique carried out in this study was interviews. The interviewing is an unstructured interview. The researcher only prepares an outline about the things that will be asked, and then the questions develop from the interview process that has been carried out. Interviews were conducted with members of the arts group, the head of the arts group, and the audience.

\subsubsection{Documentation study}

This study also uses documentation studies in the process of collecting data. Documentation studies were carried out by collecting documents in the field related to Barongan Kusumojoyo art performances in Demak Regency.

\subsection{Data Analysis Technique}

\subsubsection{Data Reduction}

Data reduction in this study was carried out by grouping data that had been obtained from the field. Data reduction is done by sharpening, classifying, organizing, and removing unnecessary ones so that the final conclusions can be drawn and verified [8].

\subsubsection{Data Presentation}

Presentation of data is done by compiling a set of existing information to give the possibility of drawing conclusions and taking action. The presentation used is in the form of narrative text which is a simplification of the amount of information into a simplified unitary form [8].

\subsubsection{Drawing Conclusion}

Drawing conclusions is the last and most important stage of the research process. Data that has been collected and analyzed is then processed for conclusions. 


\subsection{Data Validity Technique}

Referring to Moleong's opinion [9], the validity technique of the data carried out in this study were:

\subsubsection{Extension of participation}

Extension of participation is done by increasing the time of research until data saturation occurs. This aims to get as much data as possible.

\subsubsection{Triangulation}

Triangulation is done by using something else outside the data for checking purposes or as a comparison to the data obtained. Triangulation was carried out in three ways namely source triangulation, method triangulation, and theory triangulation.

\subsubsection{Examination of colleagues}

Peer examination techniques are carried out by exposing the temporary results or the final results obtained in the form of discussions with colleagues.

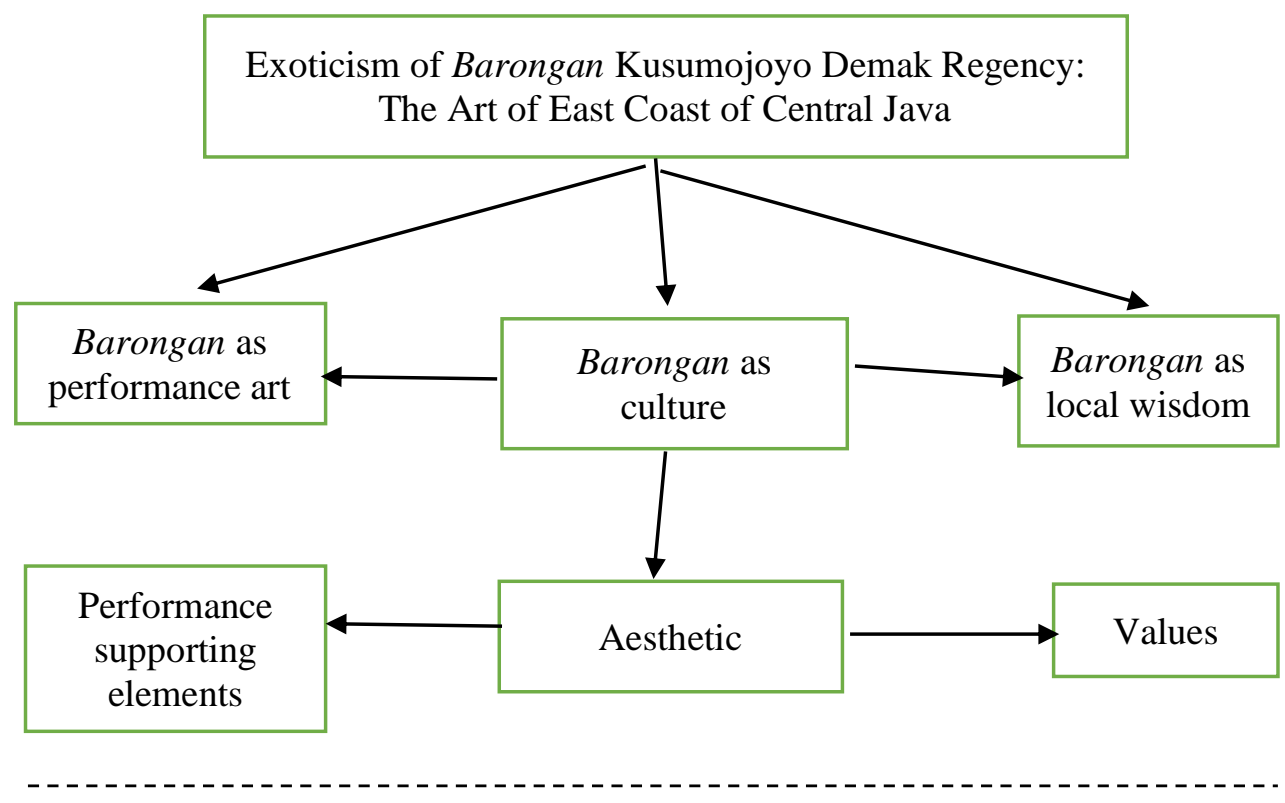

Figure 1: Research Concept Exoticism of Barongan Kusumojoyo Demak Regency: The Art of East Coast of Central Java

Barongan Kusumojoyo Arts of Demak Regency is one of the arts in the eastern coastal region of Central Java. Barongan Kusumojoyo Art is located in Gebang Village, Bonang 
District, Central Java. This art group has more than 80 members. Barongan Kusumojoyo arts group often performed at various events and several times became ambassadors representing Demak Regency. Barongan Kusumojoyo was performed in various kinds of events, such as circumcision, wedding, village cleaning, haul or nadzar, ruwatan, and events made by agencies in Demak Regency. This art group led by Pak Hartono held practice before the performance, and even improvised without practice.

\subsection{Forms of the Barongan Kusumojoyo Show}

Barongan Kusumojoyo Arts of Demak Regency is one of the traditional arts originating from Central Java. The Barongan Kusumojoyo art show in Demak Regency consists of 5 parts, namely:

\subsubsection{Jathilan}

Jathilan is a performance process that displays dances using kuda lumping. Jathilan is displayed as an opening for the Barongan Kusumojoyo show in Demak Regency. Jathilan dancers consist of between 10-50 dancers, according to the demands of consumers, in this case the person who hires the Barongan Kusumojoyo arts in Demak Regency. This Jathilan uses accompaniment music in the form of gamelan and western musical instruments such as drums, keyboards, and guitars. The song used is in the form of Javanese songs and dangdut songs.

\subsubsection{Barongan}

Barongan is a performance process that displays characters or figures in the form of animals and some human figures. The characters in the performance process of Barongan Kusumojoyo in Demak Regency are: (1) chickens, (2) dragons, (3) demons, (4), singo barong, (5) tigers.

\subsubsection{Songs}

What is meant by "songs" in the part of the Barongan Kusumojoyo art show in Demak Regency is like a process of connecting between shows. The song section is done as a connection from one part to another. The song is either Javanese songs and dangdut songs.

\subsubsection{Guyon Maton}

Guyon Maton is meant here as part of the comedy. After the song section, which is to listen to the singer sings the song, the next part is listening to the comedians that tell their jokes.

\subsubsection{Attractions}

The last part of the Barongan Kusumojoyo show in Demak Regency is part of the attraction. The attraction part in the Barongan Kusumojoyo art show in Demak Regency is like a magic process that displays things outside of human logic. The attractions section consists of: (1) Breaking bricks over the head, (2) Peeling coconuts using teeth, (3) Eating "razor blades" or small knives, (4) Eating needles, (5) Breaking the coconut over the head, (6) Stab the bold stem.

\subsection{Elements of the show}

Barongan Kusumojoyo Arts is one of the performing arts groups supported by several supporting elements. The supporting elements of Barongan Kusumojoyo in Demak Regency are: 


\subsubsection{Dancers}

Dancers in Barongan Kusumojoyo in Demak Regency are dancers who plays jathilan, animal figures, and demons.

\subsubsection{Music Players}

The music players in Barongan Kusumojoyo's art are gamelan and "modern" music players

\subsubsection{Comedian}

The comedians in the Barongan Kusumojoyo art show in Demak Regency are players who are in the part of Guyon Maton

\subsubsection{Attraction Handler}

The attraction handler is the leader of the attraction show section. This player regulates and is responsible for the attraction section.

\subsubsection{Singers}

The singers in the show are sindhen who also sing dangdut songs.

\subsubsection{Property}

The property in the Barongan Kusumojoyo art show in Demak Regency is the tools used to support performances such as kuda kepang, flags and whips.

\subsubsection{Offerings}

The offerings in the Barongan Kusumojoyo art show in Demak Regency are used during the attraction section. These offerings are used to honor the ancestors of the area used for the stage.

\section{CONCLUSION}

Barongan Kusumojoyo Demak Regency located in Gebang Village, Bonang District, Demak Regency Central Java consists of 5 parts, namely: jathilan, barongan, song, guyon maton, attractions. Barongan Kusumojoyo Arts is one of the performing arts groups supported by several supporting elements. The supporting elements of Barongan Kusumojoyo in Demak Regency are: dancers, music players, comedian, attraction handler, singers, property, and offerings.

\section{REFERENCES}

[1] A. Maladi, "Kesenian Tradisional Sebagai Sarana Strategi Kebudayaan,” Nusa, vol. 12, no. 1, pp. 90-100, 2017.

[2] L. Andri, "Kesenian Barongan Kabupaten Pati dalam Pergeseran Budaya," Nusa, vol. 12, no. 2, pp. 90-99, 2017.

[3] Karyono, Model Pertunjukan Barongan Anak sebagai Transmisi Budaya, vol. 12, no. 2. 2013.

[4] T. R. Rohidi, Ekspresi Seni Orang Miskin. Bandung: Penerbit Nuansa, 2000.

[5] N. Iswantara, Kritik seni, seni kritik. Semarang: Gigih Pustaka Mandiri, 2016. 
[6] Y. Heriyawati, Seni Pertunjukan dan Ritual. Yogyakarta: Penerbit Ombak, 2016.

[7] T. Parsons, Talcott Parsons dan Pemikirannya. Yogyakarta: Tiara Wacana, 1990.

[8] F. T. Sumaryanto, Pendekatan Kuantitatif dan Kualitatif dalam Penelitian Pendidikan Seni. Semarang: Jurusan Sendratasik Fakultas Bahasa dan Seni Universitas Negeri Semarang, 2007.

[9] L. J. Moleong, Metodologi Penelitian Kualitatif (Sebuah Revisi). Bandung: PT. Remaja Rosdakarya, 2008. 